\title{
CITRA DIRI PADA PEREMPUAN BERHIJAB PENGGUNA ROKOK ELEKTRIK
}

\author{
Mutia Mawardah ${ }^{1}$, Imam Budi Darma ${ }^{2}$ \\ Dosen Universitas Bina Darma ${ }^{1}$, Mahasiswa Universitas Bina Darma ${ }^{2}$ \\ Jalan Jenderal Ahmad Yani No.3 Palembang \\ Surel : mutia_mawardah@binadarma.ac.id'1,imambudidarma@outlook.com²
}

\begin{abstract}
This study aims to look at the self-image of female adolescents wearing ecigarette wearing hijab. What factors affect the self-image of women who use e-cigarette wearing hijab, as well as how the self-image of women wearing e-cigarette wearing hijabs. This study uses a qualitative research design and uses a phenomenological approach to be able to see the self-image of women who use e-cigarettes. In this study, researchers used 6 sources. 2 people as research subjects, 2 people as the perpetrator informant and 2 informants know of each subject. The results of this study found that the self-image of the e-cigarette wearing hijab woman who has a self-image that is not much different. The first subject has four self-images, while the second subject also has four self-images from four self-image images. Each description that is owned by the subject is also based on several factors, namely physical condition, family condition, seeking attention, depending on smoking and expectations.
\end{abstract}

Keywords: Self Image, Electric Cigarette, Female Wearing Hijab

\begin{abstract}
Abstrak : Penelitian ini bertujuan untuk mengetahui citra diri remaja perempuan berhijab pengguna aktif rokok elektrik. Faktor apa saja yang mempengaruhi citra diri perempuan berhijab pengguna rokok elektrik, serta bagaimana gambaran citra diri perempuan berhijab pengguna rokok elektrik. Penelitian ini menggunakan desain penelitian kualitatif serta menggunakan pendekatan fenomenologi untuk dapat mengetahui citra diri perempuan berhijab pengguna rokok elektrik. Dalam penelitian ini, peneliti menggunakan 6 sumber. 2 orang sebagai subjek penelitian, 2 orang sebagai informan pelaku dan 2 orang informan tahu dari masing-masing subjek. Hasil penelitian ini menemukan bahwa citra diri perempuan berhijab pengguna rokok elektrik memiliki citra diri yang tidak jauh berbeda. Subjek pertama memiliki empat citra diri, sementara subjek kedua juga memiliki empat citra diri dari empat gambaran citra diri. Setiap gambaran yang dimiliki oleh subjek juga dipengaruhi oleh beberapa faktor yaitu keadaan fisik, teman sebaya dan kelompok, keadaan keluarga, mencari perhatian, ketergantungan merokok dan harapan.
\end{abstract}

Kata kunci: Citra Diri, Rokok Elektrik, Wanita Berhijab

\section{PENDAHULUAN}

Perempuan berhijab dalam realitanya kerap digambarkan sebagai sosok yang lemah lembut, harus mengetahui implikasi perilakunya dan tindakannya, penggambaran tersebut telah melekat dalam kognisi khalayak luas sampai saat ini, sehingga menjadikan ruang lingkup atau ranah perempuan berjilbab menjadi sangat tersekat. Tersekatnya ruang dapat dilihat hal tersebut sepenuhnya didasarkan pada kenyataan yang ada, salah satunya adalah apakah perempuan 
berhijab dikaitkan dengan rokok (simbol) yang dekat dengan maskulinitas. Perempuan berhijab menjadi suatu perdebatan mengenai keetisannya di kalangan masyarakat tertentu yang akhirnya menimbulkan berbagai anggapan. Merokok dianggap bukan sesuatu yang lumrah dan lazim dilakukan oleh perempuan apalagi menggunakan hijab, karena perempuan berhijab yang merokok dianggap sebagai ciri khas yang akan membedakan mereka dari perempuanperempuan lainnya yang tidak merokok.

Barraclough (1999) menyebutkan perempuan tidak merokok dalam jumlah besar karena adanya ketidaksetujuan budaya yang kuat mengenai perilaku merokok pada perempuan. Sementara pada saat yang bersamaan, merokok di kalangan pria dianggap sebagai budaya. Perkembangan teknologi dan perubahan gaya hidup juga telah merubah kebiasaan para pecinta rokok. Sebuah fenomena sosial baru telah muncul dalam masyarakat modern yaitu penggunaan rokok elektrik. Hal ini dikarenakan munculnya era modern dan bertambahnya jumlah pusat perbelanjaan, dan produk yang disediakan oleh pusat perbelanjaan ini terus berkembang dan mudah didapat.

Di kalangan perempuan sendiri ternyata lebih menyukai rokok elektrik yaitu Electronic cigarette atau e-cigarette merupakan salah satu metode NRT adalah suatu metode yang menggunakan media untuk mengantarkan nikotin yang dibutuhkan oleh perokok tanpa membakar tembakau. Metode ini menggunakan tenaga baterai untuk mengirimkan nikotin dalam bentuk uap, disebut ENDS (Electronic Nicotine Delivery System) untuk membakar tembakau tanpa membakarnya secara permanen (Cobb, 2010). Kegiatan menghisap rokok elektrik ibarat individu yang menghisap rokok biasa. Tujuannya sama dengan hal tersebut, yang utamanya dilakukan oleh laki-laki. Walaupun tidak mengherankan jika perempuan berhijab menghisap rokok elektrik, namun baru diusulkan gagasan bahwa merokok telah dimulai, seolah-olah di bawah perlindungan laki-laki, sekarang mulai masuk ke dalam ranah perempuan yang mengenakan hijab.

Menurut Santosa, (1993) berbagai macam penyebab perempuan menggunakan rokok akhirnya mereka mempunyai makna tersendiri ketika dirinya sudah menjadi pengguna aktif. Rokok elektrik bukan hanya sekedar pengaruh orang tua, pengaruh lingkungan teman sebaya atau pun hanya sekedar keinginan mereka pribadi. Perilaku yang kebanyakan berasal dari hasil coba-coba ini kini sudah mulai menjadi gaya hidup atau stress atau hanya sekedar mengusir kejenuhan saja.

Hingga saat ini, masyarakat masih belum mengetahui apa-apa tentang latar belakang mereka, memiliki pandangan yang buruk tentang perokok yang mengenakan 
hijab, dan kesan bahwa mereka adalah perempuan nakal atau perempuan yang tidak baik. Mereka tidak ingin diremehkan oleh masyarakat, karena tidak semua perempuan berhijab yang aktif menghisap rokok adalah perempuan yang nakal.

Semua orang ingin dihormati oleh orang lain, terutama perempuan berhijab yang masih menjadi sasaran reaksi buruk dari beberapa orang. Dalam permasalahan ini perempuan berhijab yang menggunakan rokok elektrik mempunyai maksudnya tersendiri sering dianalogikan sebagai citra diri atau gambaran diri yang ingin diperkenalkan kepada semua orang di luar dirinya.

Menurut Centi (2004), citra diri merupakan hal yang subyektif, menurut penglihatan sendiri. Keadaan dan penampilan diri pada gilirannya dipengaruhi oleh norma yang dijumpai atau dihadapi. Sedangkan menurut Prakoso (Sunastiko, 2013) citra diri mecangkup tentang penilaian penampilan, pola berpikir individu dan kondisi emosi, perilaku individu serta kepribadian di dalam diri individu secara menyeluruh.

Subjek pertama $\mathrm{J}$ adalah seorang perempuan muslimah berumur 21 tahun yang memakai hijab dengan tinggi sekitar $165 \mathrm{~cm}$, memiliki ciri kulit putih dan wajah yang cantik. $J$ adalah perempuan yang berhijab. J merupakan seorang yatim dimana ayahandanya sudah lama pergi. J tinggal bersama Ibu dan kedua saudara laki-lakinya. J merupakan perempuan aktif pengguna rokok elektrik.

Subjek kedua yaitu $\mathrm{H}, \mathrm{H}$ adalah seorang perempuan muslimah kedua yang juga seorang perokok aktif terutama rokok elektrik. H memiliki ciri-ciri kulit putih dan wajah cantik putih bersih, tinggi $\mathrm{H} 165 \mathrm{~cm}$ berat badan $60 \mathrm{~kg}$ umur subjek 22 tahun dan subjek $H$ menggunakan hijab dirumah maupun di luar rumah. $\mathrm{H}$ merupakan anak bungsu dari empat bersaudara.

Citra diri tidak tercipta begitu saja, Ada beberapa faktor yang mempengaruhi citra diri. Menurut Mappiare (1995) membagikan beberapa faktor yang dapat mempengaruhi citra diri, yaitu faktor keadaan fisik, teman sebaya kelompok dan keadaan keluarga. Faktor keadaan fisik meliputi perbedaan keadaan, perasaan malu dan rendah diri. Faktor teman sebaya kelompok meliputi penerimaan kelompok terhadap diri seseorang, rasa ikut serta dalam kelompok, memperkuat self-image. Faktor keadaan keluarga meliputi situasi rumah-tangga, sikap mendidik orangtua, pergaulan dan pola hubungan antar anggota keluarga.

\section{METODOLOGI PENELITIAN}

Metode penelitian kualitatif adalah metode penelitian yang bertujuan untuk mengembangkan pemahaman tentang pengalaman, interaksi, dan pola perilaku 
manusia. Penelitian kualitatif adalah penelitian yang bertujuan untuk mendeskripsikan dan menjelaskan alasan dibalik motivasi dan perilaku manusia (Bursztyn, 2006). Sedangkan, pendekatan penelitian kualitatif dengan pendekatan fenomenologi adalah suatu model yang mendeskripsikan kesadaran atau pengalaman seseorang atau lebih tentang suatu fenomena.

Subjek penelitian ini adalah dua orang wanita yang aktif mengenakan jilbab melalui rokok elektrik unik miliknya. Peneliti lebih memperhatikan studi citra diri dengan menggunakan metode fenomenologi. Dalam penelitian ini peneliti menggunakan 6 narasumber, yaitu 2 orang objek penelitian, 2 orang terdakwa pelanggar, dan 2 orang terdakwa yang mengetahui masing-masing objek penelitian. Teknik yang digunakan dalam penelitian ini adalah gabungan antara teknik observasi, wawancara dan pencatatan. Saat menguji keabsahan data, metode penelitian kualitatif menggunakan validitas dan verifikasi data menggunakan triangulasi data. Triangulasi dibagi menjadi triangulasi sumber, triangulasi teknologi pengumpulan data, triangulasi waktu, dan triangulasi teoritis. (Poerwandari, 2001).

\section{HASIL DAN PEMBAHASAN}

Gambaran Citra Diri Perempuan Berhijab Pengguna Rokok Elektrik

\section{Tema 1: Penilaian Penampilan}

Setelah menjadi pengguna aktif rokok elektrik membuat $\mathrm{J}$ merasa dirinya perempuan gaul dan mengganggap dirinya adalah perempuan high class, perempuan lebih tinggi statusnya dibanding dengan perempuan yang tidak menghisap rokok elektrik

Sedangkan subjek $\mathrm{H}$ memandang dirinya adalah perempuan yang cantik secara fisik perempuan yang cantik punya kebebasan untuk melakaukan hal apapun termasuk menghisap rokok elektrik.

\section{Tema 2: Pola Berpikir}

Dengan menghisap rokok elektrik J berpikir bahwa itu urusan dia bukan urusan orang lain masalah-masalah dia, itu adalah pilihan dia bukan orang lain yang menentukan pilihan dalam hidupnya.

Sedangkan subjek $\mathrm{H}$ mengalami perbedaan dari teman lingkungan sekitarnya ketika sudah menjadi seorang perokok. Kendala yang di temui subjek $\mathrm{H}$ adanya perbedaan dari orang disekitarnya sendiri yang tidak suka terhadap dirinya. Subjek $H$ menganggap dirinya bukan pengaruh buruk untuk orang lain dari ia menghisap rokok elektrik

\section{Tema 3: Kondisi Emosi}

J sedih ketika sedang menghisap rokok elektrik di dekat teman perempuannya, salah 
satu teman perempuan subjek tidak menyukai subjek J ketika sedang menghisap rokok elektrik di dekat dirinya

Sedangkan subjek H pernah mengalami sakit hati dengan perkataan temanya yang menyakitkan bagi dirinya ketika sedang menghisap rokok elektrik di dekat teman perempuannya. Tidak seharusnya seorang teman memarahi dirinya seharusnya masalah ini bisa dibicarakan secara baik-baik

\section{Tema 4: Perilaku Individu dan} Kepribadian Menyeluruh

Untuk sekarang J tidak lagi memusingkan tentang dirinya seperti apapun serta penialain orang lain tehadap dirinya setelah menjadi pengguna aktif rokok elektrik

Sedangkan subjek $\mathrm{H}$ Menunjukan kelingkungan dengan perilaku dirinya yang sebagai seorang perempuan berhijab yang menghisap rokok elektrik dan menerima apapun perkataan atau labeling negatif dari orang lain terhadap dirinya dirinya.

\section{Faktor yang Mempengaruhi Citra Diri}

\section{Pada Perempuan Berhijab}

\section{Tema 1: Keadaan Fisik}

Banyak perubahan yang $\mathrm{J}$ rasakan setelah menggunakan rokok elektrik seperti untuk menurunkan berat badan menjadi langsing. J senang dengan penurunan berat badan tersebut, J juga membenci ketika berat badan naik.

Menghisap rokok elektrik ada hal positif yang diterima oleh subjek $\mathrm{H}$ seperti rokok sebagai penurun berat badan dan rokok elektrik juga sering membuat subjek $\mathrm{H}$ merasa sesak nafas.

\section{Tema 2: Teman Sebaya dan Kelompok}

J mengetahui rokok elektrik dari kuliah dari teman sekelasnya kebetulan

pada waktu itu teman J sedang membawa rokok elektrik itu ke kampus dan mengabari J untuk datang kekampus dimana pada saat itu $\mathrm{J}$ masih berada dirumah dan disuruh untuk datang kekampus oleh temannya untuk menghisap rokok elektrik bersama dikantin belakang kampus.

Sedangkan subjek $\mathrm{H}$ mengetahui rokok elektrik dari teman sebagai rekomendasi untuk berhenti merokok tembaku dan $\mathrm{H}$ mencoba rokok elektrik tersebut.

\section{Tema 3: Keadaan Keluarga}

$\mathrm{J}$ diberi kebebasan didalam keluarga $\mathrm{J}$ tidak pernah ditanyain ketika J keluar malam oleh ibu, kakak atau adiknya. Di keluarga J tidak pernah mendapatkan perlakuan keras baik dari ibu atau kakak orang yang lebih tua darinya.

Sedangkan subjek $\mathrm{H}$, di dalam keluarga orangtua dan kakak sudah mengetahui bahwa 
subjek $\mathrm{H}$ adalah seorang perokok tetapi tidak begitu dipermasalahkan.

\section{Tema Temuan diluar Penelitian}

\section{Tema 1: Mencari Perhatian}

$\mathrm{J}$ setelah aktif dalam menghisap rokok elektrik yang dirasakan subjek $\mathrm{J}$ menjadi pusat perhatian oleh orang lain subjek $\mathrm{J}$ merasa senang ketika di perhatikan ketika sedang menghisap rokok elektrik terutama oleh lawan jenis.

Sedangkan subjek H menghisap rokok elektrik untuk mencari sensasi, bersenangsenang dan mencari perhatian lawan jenis dengan menghisap rokok elektrik apakah masih ada laki-laki yang menyukai dirinya yang mana seorang perempaun berhijab mengshiap rokok elektrik.

\section{Tema 2: Ketergantungan Merokok}

Ketika sedang mendapatkan masalah dalam hidup rokok elektrik adalah solusi subjek J sebagai sebuah penyelesaian masalah yang dihadapi seperti membuat diri lebih tenang dan damai.

Sedangkan subjek $\mathrm{H}$, Rokok elektrik adalah sumber ketenangan dalam hidup subjek $H$ sehari tanpa menghisap rokok elektrik, $\mathrm{H}$ merasa gelisah dalam hidup

\section{Tema 3: Pergaulan Bebas}

$\mathrm{J}$ bercerita selain dari kegiatan menghisap rokok elektrik $\mathrm{J}$ pernah terlibat dalam melakukan hal diluar dugaan dengan lawan jenis. Kejadian itu pada saat merayakan malam tahun baru $\mathrm{J}$ bersama kedua teman perempuannya dan beberapa pasangan pria lainnya untuk menginap. disebuat hotel sehabis merayakan malam tahun baru.

\section{Tema 4: Harapan}

J secara sadar mengambil keputusan dalam dirinya untuk menjadi perempuan berhijab menghisap rokok elektrik, J siap menanggung semua resiko yang didapat dari menghisap rokok elektrik. J menyadari semua dampak negatif dari menghisap rokok elektrik.

Sedangkan subjek H Untuk kedepannya $\mathrm{H}$ ingin berhenti dari menghisap rokok elektrik, ia sering memikirkan dimana dirinya seorang perempuan yang kedepannya akan menikah dan $\mathrm{H}$ tidak menginginkan terjadi hal yang negatif dari ia menghisap rokok elektrik ini untuk kedepannya.

\section{SIMPULAN}

Berdasarkan hasil analisis peneliti, dapat disimpulkan bahwa citra diri dari kedua tema yang mereka tunjukkan memiliki gambaran garis besar. Kedua subjek dalam penelitian ini adalah $\mathrm{J}$ dan $\mathrm{H}$ mereka menunjukan bentukbentuk dari citra diri, mulai dari, penilaian penampilan, pola berpikir, kondisi emosi, perilaku Individu dan kepribadian 
menyeluruh dan beberapa tema temua lain yang ditemukan pada kedua subjek.

Hasil penelitian pada kedua subjek terdapat perbedaan pada tema pola berpikir dan keadaan fisik. Pada tema pola berpikir subjek $\mathrm{J}$ dirinya adalah pembuat pilihan dalam hidup orang lain tidak berhak menenetukan apapun dalam pilihannya termasuk menggunakan rokok elektrik. Tema kedua keadaan fisik, $\mathrm{J}$ sangat membenci berat badan ketika naik menggunakan rokok elektrik sebagai metode penurunan berat badan.

Sedangkan, subjek kedua $\mathrm{H}$ pada tema pola berpikir subjek kedua $\mathrm{H}$ merasa dirinya menjadi perbedaan orang lain dan subjek $\mathrm{H}$ merasa bukan pengaruh buruk untuk orang lain dengan perilakunya yang aktif menghisap rokok elektrik. Sedangkan pada tema keadaan fisik, $H$ memandang dirinya perempuan cantik secara fisik perempuan cantik bebas berbuat apa saja dalam hal apapun termasuk menggunakan rokok elektrik.

Faktor penyebab citra diri pada kedua subjek penelitian ini cenderung sama seperti faktor teman sebaya dan kelompok dan keadaan keluarga, terdapat persamaan pada faktor temuan beberapa faktor tersebut seperti mencari perhatian, ketergantungan merokok dan harapan.

Simpulan dalam penelitian ini yaitu kedua partisipan melewati semua tahapan yang ada, terdapat dua perbedaan pada tema pola berpikir dan keadaan fisik pada subjek $\mathbf{J}$ dan H. Di dalam proses wawancara dan observasi di temukan beberapa temuan lain diluar penelitian pada kedua subjek, temuan lain tersebut didapatkan persamaan antara lain pada tema mencari perhatian, ketergantungan dan harapan. 
DAFTAR RUJUKAN

Anggraini, N. P. (2019). Self Image of Male Adolescents Who Does Face Treatment Routinely at Skin Care Clinic in Yogyakarta , Indonesia. 168-172.

Anggarianto, O. (2018). Konsep diri pada wanita perokok. Fakultas Psikologi UMS, 1-8.

Antara, H., Diri, K., Pola, D., Otoritatif, A., Citra, D., Pada, D., Melakukan, Y., Wajah, P., \& Klinik, D. (2017).

Arifin, N. (2018). Konstruksi Makna Bagi Arifin, N. (2018). Konstruksi Makna Bagi Wanita Pengguna Vape di Kota Pekanbaru. Journal of Chemical Information and Modeling, 53(9), 1689-1699.

https://doi.org/10.1017/CBO978110741 $\underline{5324.004}$

Damayanti, A. (2016). Penggunaan Rokok Elektronik di Komunitas Personal Vaporizer Surabaya. Jurnal Berkala Epidemiologi, 4(2), 250-261. https://doi.org/10.20473/jbe.v4i2.2016.2 $\underline{50}$

Lestari, D. (2017). Gambaran Faktor Faktor Yang Menyebabkan Remaja Putri Untuk Merokok. JPPP - Jurnal Penelitian Dan Pengukuran Psikologi, 1(1), 46. https://doi.org/10.21009/jppp.011.07.

Margowati, Sri. Zuhriyah, E. (2017). Pendapat Perempuan Tentang Dampak Merokok Dan Kawasan. The 6th URECOL, 407-414. Retrieved from http://journal.ummgl.ac.id/index.php/ur ecol/article/view/1616

MN Silfana. (2016). Tinjauan umum tentang citra diri dan jilbab. Journal Citra Diri Dan Jilbab, $16-53$.
https://doi.org/10.1017/CBO9781107415 $\underline{324.004}$

Pratikasari, N., \& Handoyo, P. (2014). Makna Merokok Bagi Perempuan Berjilbab Di Surabaya. Paradigma, 2(3), 1-7. http://ejournal.unesa.ac.id/article/12222/ 39/article.pdf 